\title{
A Novel Member of the Genus Nepovirus Isolated from Cucumis melo in Japan
}

\author{
Yasuhiro Tomitaka, Tomio Usugi, Fumitoshi Yasuda, Hiroshi Okayama, and Shinya Tsuda
}

First, second, and fifth authors: National Agricultural Research Center, Tsukuba, Ibaraki 305-8666, Japan; and third and fourth authors:

Tottori Prefectural Agriculture and Forest Research Institute, Hokuei, Tottori 689-2221, Japan.

Accepted for publication 7 October 2010.

\section{ABSTRACT}

Tomitaka, Y., Usugi, T., Yasuda, F., Okayama, H., and Tsuda, S. 2011. A novel member of the genus Nepovirus isolated from Cucumis melo in Japan, Phytopathology 101:316-322.

An unusual virus was isolated from a Japanese Cucumis melo cv. Prince melon plant showing mild mottling of the leaves. The virus had a broad experimental host range including at least 19 plant species in five families, with most infected plants showing no symptoms on inoculated and uninoculated systemically infected leaves. The virus particles were spherical, approximately $28 \mathrm{~nm}$ in diameter, and the coat protein (CP) had an apparent molecular mass of about $55 \mathrm{kDa}$. The virus possessed a bi-partite genome with two RNA species, of approximately 8,000 and 4,000 nucleotides. Both genome components for the new virus were sequenced. Amino acid sequence identities in $\mathrm{CP}$ between the new virus and previously characterized nepoviruses were found to be low (less than 27\%); however, in phylogenetic reconstructions the closest relationship was revealed between the new virus and subgroup A nepoviruses. These results suggest that the new virus represents a novel member of the genus Nepovirus. A new name, Melon mild mottle virus, has been proposed for this new virus.
Cucurbits are important vegetable crops in Japan being cultivated throughout the country. Melon (Cucumis melo L.), widely cultivated in tropical and temperate regions of the world, is especially popular. Several cultivars of melon are bred in Japan, and are classified into four major types: green flesh netted melon, red flesh netted melon, smooth skin melon, and oriental pickling melon (19). Oriental pickling melons such as C. melo cv. Prince, bred by crossing $C$. melo cv. makuwa smooth skin and others, are widely cultivated and distributed throughout Japan and are popular because of their lower prices (10). To support a lower cost cultivation system for such melons, Japan usually imports cheap melon seedlings.

Several pathogenic agents of melons, including viral diseases, have previously been reported worldwide. These include $\mathrm{Cu}$ cumber mosaic virus (CMV), Cucumber green mottle mosaic virus (CGMMV), Melon necrotic spot virus (MNSV), Squash mosaic virus (SMV), Tobacco ringspot virus (TRSV), Tomato ringspot virus (ToRSV), and Watermelon mosaic virus (WMV) (25). These viruses induce severe mosaic or necrotic symptoms on infected melon leaves and fruits, and cause major economic losses. There are no reports of cucurbit viruses that do not cause serious symptoms in a natural infection. In Japan, ToRSV is the only nepovirus reported to infect Cucumis plants (25). ToRSV infection induces chlorotic ringspots and spots on upper noninoculated melon leaves, leading to the development of typical mosaic symptoms. However, these symptoms do not appear on newly emerging leaves.

During a field survey in 2008, a virus-like disease was observed on the oriental pickling melon, $C$. melo cv. Prince, in the Tottori Prefecture, Japan. Infected plants showed a mild mottling of the true leaves, which was only observed during the early growth period. Therefore, this infection did not lead to economic damage or losses in fruit production. The phenomenon suggested a

Corresponding author: S. Tsuda; E-mail address: shinyat@affrc.go.jp

doi:10.1094/PHYTO-06-10-0150

(c) 2011 The American Phytopathological Society pathogenic infection, but it was distinct from previously reported viral infections of melon. To identify the cause of the infection, we first isolated the pathogen and determined its host range, molecular properties and complete genome sequence. In addition, phylogenetic analyses of genomic sequences were conducted. These analyses indicated that the virus is a novel member of the genus Nepovirus.

\section{MATERIALS AND METHODS}

Virus isolation and host range test. Virus isolation was carried out from a single local lesion using Chenopodium quinoa. Nicotiana benthamiana was used for virus propagation. Host range analysis was examined by mechanical inoculation with sap prepared from infected $N$. benthamiana leaves using Carborundum as an abrasive. The plants tested and symptoms observed are listed in Table 1. Inoculated plants were kept in a greenhouse at $23^{\circ} \mathrm{C}$ under conditions of $16 \mathrm{~h}$ day/8 $\mathrm{h}$ night. The symptoms were observed for 3 weeks, and virus infection of inoculated plants was confirmed by back-inoculation to $C$. quinoa and reverse transcription-polymerase chain reaction (RT-PCR).

Virion purification. The virus isolate was propagated in and purified from $N$. benthamiana. Inoculated leaves were homogenized in $0.1 \mathrm{M}$ phosphate buffer $(\mathrm{pH} 7.0)$ containing $10 \mathrm{mM}$ sodium sulfite as an antioxidant. The extract was filtered through double-gauze and a $30 \%$ volume of chloroform was added to the extract and mixed well. The mixture was centrifuged at 4,500 $\times g$ for $15 \mathrm{~min}$ at $4^{\circ} \mathrm{C}$ and the supernatant centrifuged at $140,000 \times g$ for $120 \mathrm{~min}$ at $4^{\circ} \mathrm{C}$. The precipitate was resuspended in $0.05 \mathrm{M}$ phosphate buffer ( $\mathrm{pH}$ 7.0) and further clarified by 10 to $40 \%$ (wt/wt) linear sucrose density gradient centrifugation at $140,000 \times g$ for $180 \mathrm{~min}$ at $4^{\circ} \mathrm{C}$. Fractionated virus particles were resuspended in $0.05 \mathrm{M}$ phosphate buffer ( $\mathrm{pH} 7.0$ )

Electron microscopy. Purified virus particles were negatively stained with $2 \%$ phosphotungstic acid solution and observed under a transmission electron microscope (JEOL, Tokyo, Japan). Average diameter of virus particles was calculated from 20 particles. 
Analysis of viral coat protein and RNAs. Virus particle proteins were analyzed by subjecting purified virus to sodium dodecyl sulfate-polyacrylamide gel electrophoresis (SDS-PAGE), and staining of the separated bands with Coomassie Brilliant Blue. Amino acid sequence of the N-terminus of coat protein (CP) was determined using the procise 494 HT protein sequencing system by Takara Bio Inc. (Shiga, Japan). Viral RNAs were extracted from purified virus using the RNeasy plant RNA isolation kit (QIAGEN, Hilden, Germany). Viral RNAs were loaded on 0.1 M MOPS agarose gels containing formamide, which were stained with ethidium bromide. RNA from Tobacco mosaic virus $\mathrm{OM}$ isolate was used as a size marker.

RT-PCR. Because the melon virus was suspected to be related to nepoviruses of subgroup A or B based on the analysis of viral morphology, CP, and RNAs, the nucleotide sequences of RNA1 and RNA2 were aligned and degenerate primers (Table 2) were designed from each conserved domain. For RNA1, A1F2/A1R2, A1F3/A1R3, A1F1/oligo dT, A1F17/A1R5, and A1F9/A1R4 primer sets were used for amplification. A1R8 primer was used for $5^{\prime}$ rapid amplification of cDNA ends (RACE) analysis. For RNA2, A2F1/oligo dT and A2F2/A2R1 primer sets were used for amplification. A2R6 primer was used for 5' RACE analysis. Nucleotide sequences of the amplicons were determined using additional virus-specific primers (Table 2). Primers used for amplification and sequencing are listed in Table 2. First-strand cDNA synthesis was performed using ReverTra Ace reverse transcriptase (TOYOBO, Tokyo, Japan). After RT for $60 \mathrm{~min}$ at $42^{\circ} \mathrm{C}$, PCR was carried out with $\mathrm{KOD}$ plus polymerase (TOYOBO) and the following conditions: $96^{\circ} \mathrm{C}$ for $2 \mathrm{~min}$ followed by 30 cycles of $30 \mathrm{~s}$ at $96^{\circ} \mathrm{C}, 30 \mathrm{~s}$ at 45 or $50^{\circ} \mathrm{C}$, and $3 \mathrm{~min}$ at $68^{\circ} \mathrm{C}$, with a 10 -min extension at $68^{\circ} \mathrm{C}$. PCR products were separated by $1 \%$ agarose gel electrophoresis. Expected cDNA fragments were extracted from the gels using the QIAquick Gel Extraction Kit (QIAGEN). To detect the virus in host range tests, we designed the viral-specific primer A1F7 (5'-GACTT CCACATTATGCGGCT-3'). A1F7 and oligo dT primers were used for RT-PCR to detect this new melon virus. This sequence is located near the 3' end of RNA1 (nucleotide [nt] 6974 to 6993).

Sequencing. Nucleotide sequences of extracted cDNA fragments were determined by a primer walking method using BigDye Terminator v1.1 Cycle Sequencing Ready Reaction Kit and Applied Biosystems Genetic Analyzer DNA model 3100 (Applied Biosystems, Foster City, CA). Assembly of sequence fragments was performed with BIOEDIT version 5.0 .9 (7) or ATGC version 4.0 (Genetyx Corporation) programs. 5'-terminal sequences of the virus genome were determined using $5^{\prime}$-RACE system for rapid amplification of cDNA ends version 2.0 (Invitrogen, Carlsbad, CA), according to the manufacturer's instruc-

TABLE 1 . Host range and symptomatology of the virus

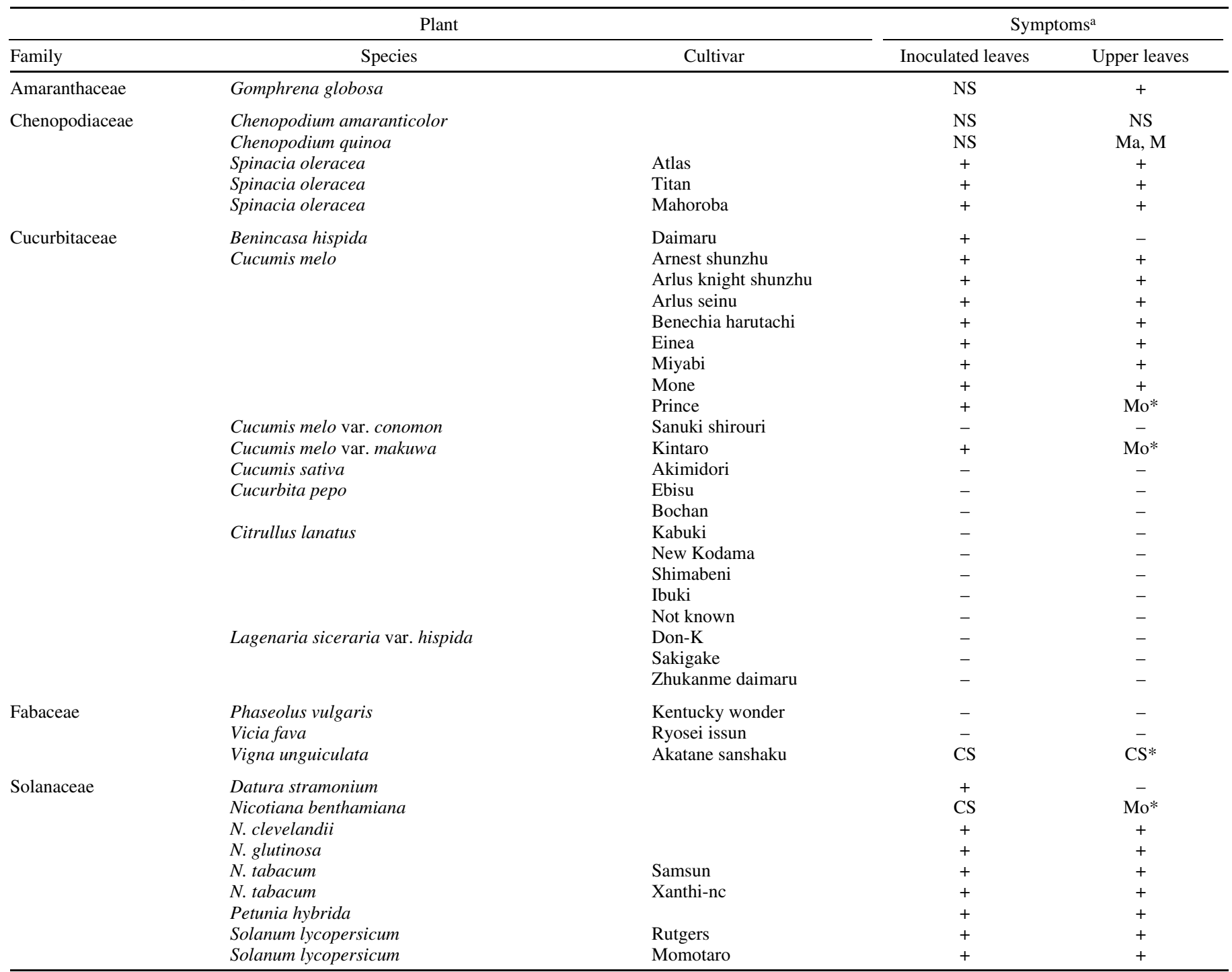

\footnotetext{
${ }^{a}$ Symptoms on inoculated and upper leaves. At least three plants were inoculated. CS, chlorotic spot; M, mosaic; Ma, malformation; Mo, mottling; NS, necrotic
} spot; +, latent infection; -, no infection; and *, symptom recovery of newly emerged leaves on inoculated plants. 
tions. The complete nucleotide sequences of the virus RNA1 and RNA2 were deposited in GenBank (accession numbers AB518485 and AB518486, respectively).

Identities and phylogenetic analyses. Percentage of identities between the deduced amino acid sequence of the new melon virus and that of other Nepovirus species were calculated using GENETYX version 10 (Genetyx Corporation). Multiple sequence alignment was performed using the CLUSTALX program (9). Gaps were removed by BIOEDIT version 5.0.9 (7). The genetic relationships of the viruses were investigated by the maximumlikelihood (ML) algorithm of TREEPUZZLE version $5.0(22,23)$. In this analysis, 1,000 puzzling steps were calculated using the Dayhoff matrix (1). Inferred gaps in the multiple alignments were treated as missing data. The calculated trees were displayed using TREEVIEW (18).

\section{RESULTS AND DISCUSSION}

A virus-like infection occurred suddenly on $C$. melo cv. Prince at Tottori Prefecture, Japan in 2008 (Fig. 1A). Although the plant showed mild mottling on young systemic leaves during the early growth stage just after transplantation into the fields (Fig. 1B), these symptoms disappeared quickly, resulting in no economic damage or loss of melon production. Based on these symptoms, it was suspected that a virus was the causal agent. Therefore, sap from original melon leaves was used to inoculate 2-week-old $C$. quinoa plants. As necrotic lesions appeared on inoculated $C$. quinoa leaves, single lesion isolation was subsequently carried out a total of three times. Pathogens established as isolates were then propagated in $N$. benthamiana for use in subsequent experiments. To fulfill Koch's postulates, the isolated pathogen was inoculated to $C$. melo cv. Prince cotyledons. Two weeks after inoculation, three to four true leaves showed slight mottling that was identical to the symptoms in the original infected plant. Following back inoculation, the isolated virus was later identified by RT-PCR and thus confirmed as a pathogen of this disease. In addition, $C$. quinoa and $C$. melo cv. Prince were inoculated with a purified preparation of this new melon virus which also induced the original symptoms. Thus, Koch's postulates were fulfilled.

To estimate the host range of the virus, 26 plant species from five families were used, as shown in Table 1 . The virus mainly infected plants of the family Cucurbitaceae, and the infection was symptomless in most of them. Only $C$. melo cv. Prince and $C$. melo var. makuwa cv. Kintaro showed mottle symptom on systemic leaves, but these symptoms did not appear on newly emerged leaves after several weeks. $C$. quinoa and $C$. amaranticolor were susceptible to the virus, showing clear necrotic spots on inoculated and upper noninoculated leaves. Viral infection was established in Vigna unguiculata but not Phaseolus vulgaris or V. fava. Infection of most Solanaceae plants was also symptomless on inoculated and upper noninoculated leaves (Table 1). Mottling symptoms were observed on leaves of some infected melons.

To determine the morphology of the virus particles, viral fractions were subjected to electron microscopy. Numerous spherical virus-like particles were observed with an average diameter of approximately $28 \mathrm{~nm}$ (Fig. 2A). Both empty and intact particles were observed in purified fractions, while these were not seen in extracts derived from healthy melon plants. To analyze the

TABLE 2. Primers used for amplification and sequencing of genome of the new melon virus in this study

\begin{tabular}{|c|c|c|c|c|}
\hline Genome & Primer name & Sequence $\left(5^{\prime}\right.$ to $\left.3^{\prime}\right)$ & Nucleotide position & Polarity \\
\hline \multirow[t]{17}{*}{ RNA1 } & Oligo dT & ТTTTTTTTTTTTTTTTTT & PolyA tail & Antisense \\
\hline & $\mathrm{A} 1 \mathrm{~F} 2$ & TACCCKSCWCTTGTGCRGGA & $427-446$ & Sense \\
\hline & A1R2 & ATAAAATTGAYRCCATTYWAAG & $650-671$ & Antisense \\
\hline & A1R3 & TTCCCAGAYTGTGAAGCACCAAA & $2485-2507$ & Antisense \\
\hline & A1F1 & CGTGTACGGAGATGACAATCT & $5676-5696$ & Sense \\
\hline & $\mathrm{A} 1 \mathrm{~F} 4$ & CTTGTCCATGTCAGAGCGAA & $5917-5936$ & Sense \\
\hline & A1F5 & TTATATTGGAGCTTGGACAGC & $6474-6494$ & Sense \\
\hline & A1F8 & GAGTTACTAACCCGATGAGC & $7419-7438$ & Sense \\
\hline & A1R4 & TATCAAGAGGCGCTAGAACTC & $5876-5896$ & Antisense \\
\hline & A1F9 & GATTAGTGGTGTTCCTCGACG & $2340-2360$ & Sense \\
\hline & $\mathrm{A} 1 \mathrm{~F} 10$ & AATTTGCCAAGGGATTCGAT & $2557-2576$ & Sense \\
\hline & A1F11 & CTCACCTATTGTCGTTACCAC & $2760-2780$ & Sense \\
\hline & A1F12 & GTTGCAGACAATGGAAGATCC & $3629-3648$ & Sense \\
\hline & A1F13 & GTAAGTTCAGAGCGCATTGC & $4196-4215$ & Sense \\
\hline & A1R6 & ATTCAGCACAAGACGTGAGAT & $1577-1597$ & Antisense \\
\hline & A1R7 & CTTACATGCCATGGTCTCAGA & $961-981$ & Antisense \\
\hline & A1R8 & CATTGCCTTACACCCAGATG & $488-507$ & Antisense \\
\hline \multirow[t]{10}{*}{ RNA2 } & Oligo dT & ТTTTTTTTTTTTTTTTTT & PolyA tail & Antisense \\
\hline & $\mathrm{A} 2 \mathrm{~F} 1$ & GGTTTYRNTTTYTATGG & $3440-3457$ & Sense \\
\hline & $\mathrm{A} 2 \mathrm{~F} 2$ & GAAYTNCCDTTGGAGTACCC & $611-630$ & Sense \\
\hline & A2R1 & GCTGCTCATCGGGTTAGTAA & $3549-3568$ & Antisense \\
\hline & $\mathrm{A} 2 \mathrm{~F} 3$ & CAACACTCATTGGGAGTTAC & $3533-3552$ & Sense \\
\hline & $\mathrm{A} 2 \mathrm{R} 2$ & ACTCAGTCAAAGCCTTGCTGGTA & $3340-3362$ & Antisense \\
\hline & A2R3 & ATCCCGTGGTGAATTCTATGG & $3213-3233$ & Antisense \\
\hline & $\mathrm{A} 2 \mathrm{R} 4$ & GGATCCTTACTACGTAACGG & $2837-2856$ & Antisense \\
\hline & A2R5 & GCTGCTGCAAGAACTGAGTA & $2440-2459$ & Antisense \\
\hline & $\mathrm{A} 2 \mathrm{~F} 4$ & AATCGCAATGTGGCCCTGAC & $917-936$ & Sense \\
\hline
\end{tabular}


molecular mass of the viral $\mathrm{CP}$, purified viral particles were subjected to SDS-PAGE analysis. A major protein band migrated at approximately 55-kDa (Fig. 2B). To investigate the cleavage site between movement protein (MP) and $\mathrm{CP}$, amino acid sequence of the $\mathrm{N}$-terminus of $\mathrm{CP}$ was analyzed and found to be Ala-Asp-Cys-Pro-Ile. Nucleic acids extracted from the purified virus were completely digested by RNase A (WAKO, Osaka, Japan), but not DNase I (QIAGEN) treatment, indicating that they were represented by a single-stranded RNA genome. Nucleic acids were loaded on a MOPS agarose gel containing formamide, and two species (RNA1 and RNA2) were observed, approximately 8,000 and 4,000 nucleotides in length, respectively (Fig. 2C).

The particle morphology, number and size of the genomic RNA molecules, and the size of CP suggested that it resembled species from the genus Nepovirus, family Secoviridae (21). Particles of bipartite members of the family Secoviridae sediment as three components in sucrose gradient, components $\mathrm{M}$ and $\mathrm{B}$ contain a single molecule of RNA1 and RNA2, respectively, and component $\mathrm{T}$ contains empty particles (3). The virus particles in the present study formed three adjacent bands in a sucrose density-gradient centrifugation, indicating that the virus is composed of the same components T, M, and B. Comoviruses and fabaviruses have two coat polypeptides (about 40 and $20 \mathrm{kDa}$ ), whereas nepoviruses have a single coat polypeptide species (about $55 \mathrm{kDa})(3,8,17)$. Thus, the particle properties of the new melon virus resembled those of Nepovirus species.

To address this possibility, the complete nucleotide sequences of RNA1 and RNA2 were determined. Schematic genome organization revealed is shown in Figure 3. RNA1 is 7,727 nts long, excluding poly (A) tail. RNA1 encodes a single open reading frame (ORF) that starts at the 5' AUG (nt 112 to 114) and terminates at UAG (nt 7054 to 7056). The polypeptide encoded
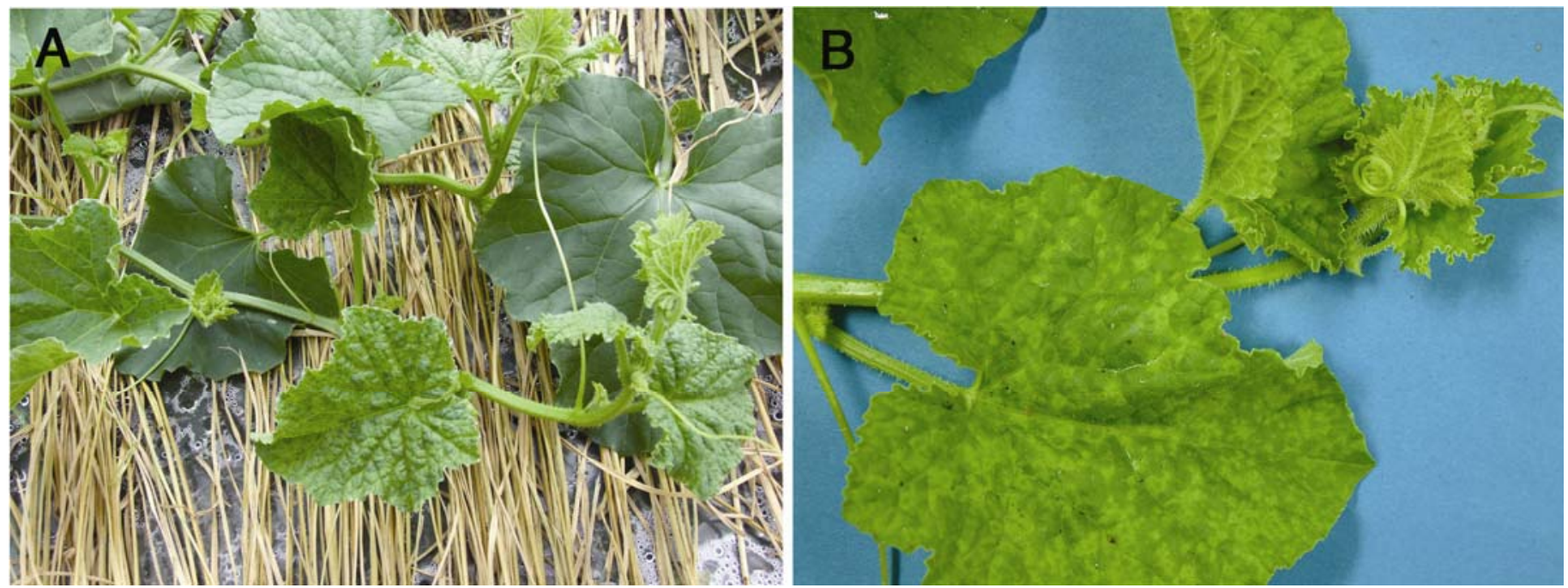

Fig. 1. Typical symptoms on Cucumis melo cv. Prince observed in field on A, leaves and $\mathbf{B}$, tip of infected plant.

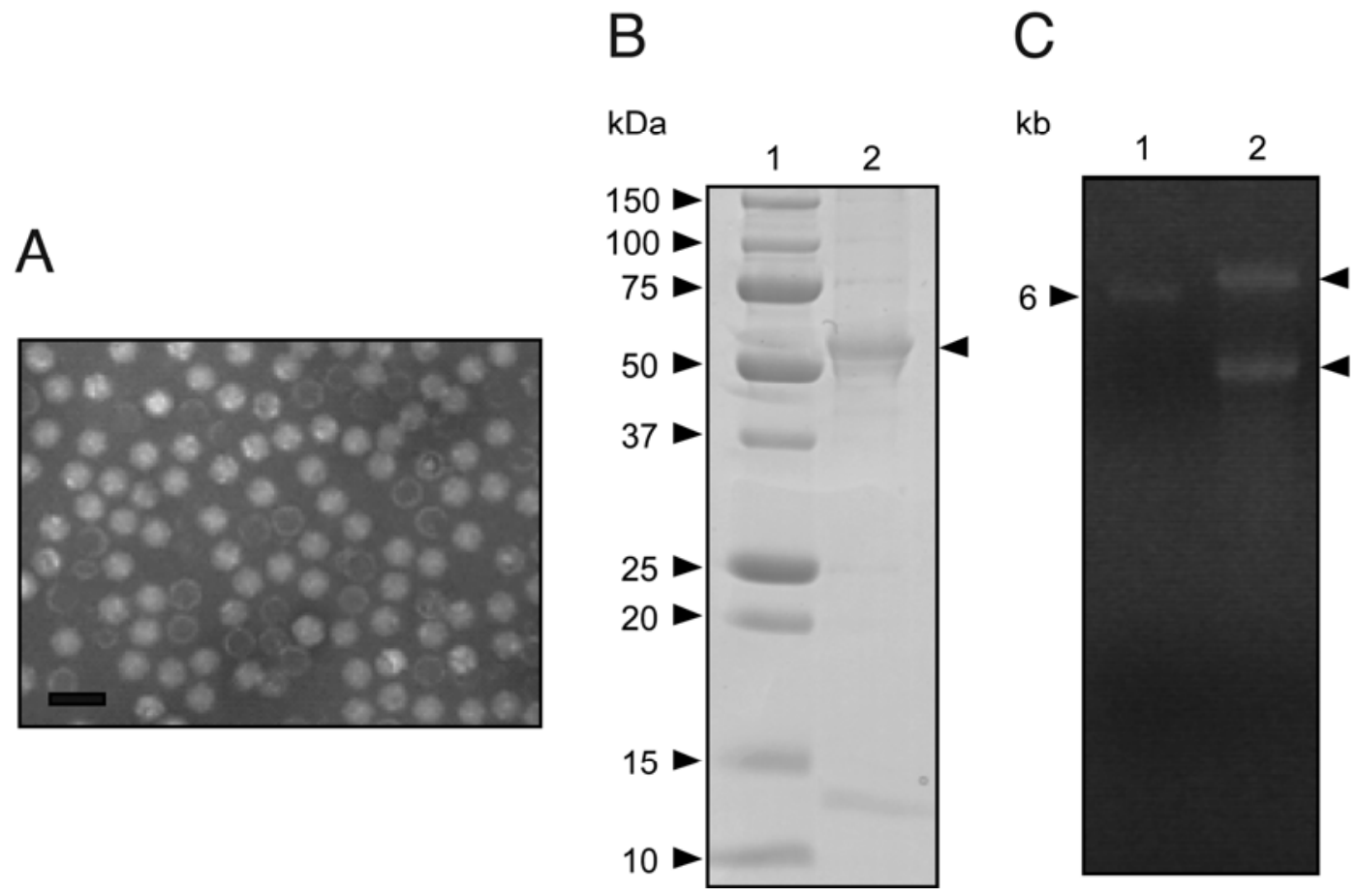

Fig. 2. A, Electron micrograph of purified viral particles. Scale bar, $50 \mathrm{~nm}$. B, Sodium dodecyl sulfate-polyacrylamide gel electrophoresis analysis of coat protein. Lanes 1 and 2 indicate molecular marker and coat protein of melon virus, respectively. C, Electrophoresis of genomic RNA of isolate. Lanes 1 and 2 indicate genomic RNA species of Tobacco mosaic virus OM and melon virus, respectively. 
by this ORF has a molecular mass of 252,145-Da. The 5' and 3' untranslated regions are 111 and 671 nts long, respectively. BLAST analysis of the amino acid sequence showed that the virus was definitely related to nepovirus sequences. The ORF contains consensus motifs I to VIII conserved in the RNA dependent RNA polymerases of positive-strand RNA viruses (11) (Fig. 3), and motifs A to $\mathrm{C}$ of the NTP-binding helicase (HEL) of superfamily 3 of positive-strand RNA viruses $(6,11)$. In addition, it encodes the catalytic triad of $\mathrm{H}, \mathrm{E} / \mathrm{D}$, and $\mathrm{C}$ conserved in cysteine proteases (C-Pro) $(2,5,15)$ (Fig. 3). A leucine, at amino acid position 1412 of the deduced polyprotein of RNA1, was found in the substrate binding pocket of protease as described for nepoviruses of subgroup A or B (15). The viral genome-linked protein (VPg) is thought to be located between the HEL and C-Pro domains, by analogy with comoviruses and nepoviruses, although we were unable to find the nepovirus and comovirus VPg consensus sequence reported by Mayo and Fritsch (16).

RNA2 is 3,854 nts long excluding its poly (A) tail. RNA2 encodes an ORF that starts at AUG (nt 122 to 124) and stops at UGA (nt 3,482 to 3,484). The polypeptide encoded by the ORF has molecular mass of 122,184-Da. The $5^{\prime}$ and $3^{\prime}$ untranslated regions are 121 and $370 \mathrm{nts}$ long, respectively. BLAST analysis of the nucleotide and amino acid sequences of RNA2 showed them to be related to nepoviruses. The cleavage site between MP and $\mathrm{CP}$ was defined as M/A based on amino acid sequencing of the $\mathrm{N}$ terminus of the CP (Fig. 3). Protease from subgroup $\mathrm{C}$ nepoviruses has a histidine as a conserved amino acid in the substrate binding pocket, whereas subgroup $\mathrm{A}$ and $\mathrm{B}$ nepoviruses and the new melon virus have a leucine in the substrate-binding pocket of their proteases ( 21 and this study). The proteases of subgroup A and $\mathrm{B}$ nepoviruses cleave a variety of cleavage sites including $\mathrm{K} / \mathrm{A}, \mathrm{K} / \mathrm{S}, \mathrm{R} / \mathrm{G}, \mathrm{R} / \mathrm{A}, \mathrm{C} / \mathrm{A}, \mathrm{C} / \mathrm{S}$, or $\mathrm{G} / \mathrm{E}$. Interestingly, the $\mathrm{M} / \mathrm{A}$ cleavage site observed at the junction between $\mathrm{MP}$ and $\mathrm{CP}$ in the new melon virus is a new cleavage site. The deduced molecular mass of the CP was $58,360-\mathrm{Da}$, which is close to the apparent molecular mass determined by the SDS-PAGE analysis. The conserved nepovirus CP motif $(13,14)$ was located in RNA2, including the FYGR motif in the C-terminus. In addition, the ORF also contained the LPL motif in the putative MP domain (12). Nepovirus subgroup C has a long 3' UTR (approximately $1.4 \mathrm{~kb})(3,4,20)$ in comparison with those of subgroups A and B, which are less than $1 \mathrm{~kb}$ in length. The $3^{\prime}$ UTR of the melon virus RNA1 is $671 \mathrm{nts}$ long, while that of RNA2 is $370 \mathrm{nts}$ long. The genome organization and a set of conserved motifs of the new melon virus confirmed that the virus is a member of the genus Nepovirus, subgroup A or B.
Viral species of the family Secoviridae are classified according to identities of $\mathrm{CP}$ and Pro-Pol, defined as the sequence comprised between the conserved protease CG motif and the conserved polymerase GDD motif sequences $(3,21)$. We therefore compared amino acid sequences between the virus and other Nepovirus species (Table 3). Pro-Pol region amino acid sequence identities were remarkably low when compared with subgroups A to $\mathrm{C}$ with ranges of 31.3 to $52.2 \%, 42.7$ to $45.4 \%$, and 39.4 to $47.0 \%$, respectively. The percentages of amino acid sequence identity in the $\mathrm{CP}$ gene were also remarkably low, with ranges of 25.3 to $26.1 \%, 21.8$ to $26.9 \%$, and 22.1 to $25.8 \%$ for subgroups A, $\mathrm{B}$, and $\mathrm{C}$, respectively (Table 3 ). Deduced amino acid sequences from the entire polyprotein from RNA1 and RNA2 were compared with those of other nepoviruses and again found to have low levels of identities: 15.2 to $35.7 \%$ for RNA1 and 14.3 to $23.1 \%$ for RNA2. Criteria demarcating species in the genus Nepovirus are less than $75 \%$ sequence identity in the deduced amino acid sequence of $\mathrm{CP}$ and less than $80 \%$ in the deduced amino acid sequence of the Pro-Pol domain (21). Our results

TABLE 3. Percentage of sequence identity between the deduced amino acid sequence of various regions of the genome of the new melon virus and those of other nepovirus species

\begin{tabular}{lcccc}
\hline Virus & RNA1 $^{\mathrm{a}}$ & RNA2 & Pro-Pol & CP \\
\hline Subgroup A & & & & \\
ArMV & 35.3 & 15.7 & 49.9 & 25.3 \\
GDeV & $-^{\mathrm{b}}$ & 15.9 & - & 25.9 \\
GFLV & 35.7 & 16.8 & 52.2 & 26.1 \\
RpRSV & 25.2 & 19.6 & 31.3 & N.A. $^{\mathrm{c}}$ \\
TRSV & 32.1 & 26.1 & 45.4 & 27.4 \\
Subgroup B & & & & \\
BRSV & 26.0 & 20.5 & 42.7 & 23.0 \\
CNSV & 26.3 & 20.1 & 45.4 & 21.8 \\
GCMV & 22.7 & 23.1 & 43.7 & 26.9 \\
OLRSV & - & 16.4 & - & 25.4 \\
TBRV & 27.0 & 20.9 & 44.6 & 23.7 \\
Subgroup C & & & & \\
BRV & 27.9 & 23.1 & 47.0 & 25.8 \\
BLMoV & - & 23.0 & - & 23.7 \\
CLRV & - & 21.5 & - & 23.5 \\
PRMV & 15.2 & - & 39.4 & - \\
ToRSV & 23.8 & 14.3 & 43.3 & 22.1 \\
AYRSV & - & 19.1 & - & 22.2 \\
\hline RNA1 & & & &
\end{tabular}

a RNA1 and RNA2 indicate the RNA1- and RNA2-encoded polyprotein, respectively. Pro-Pol is the region located at protease and polymerase gene (21).

b Amino acid sequence of the isolates not shown.

c Unavailable amino acid sequences as cleavage site is unknown.

\section{RNA 1}
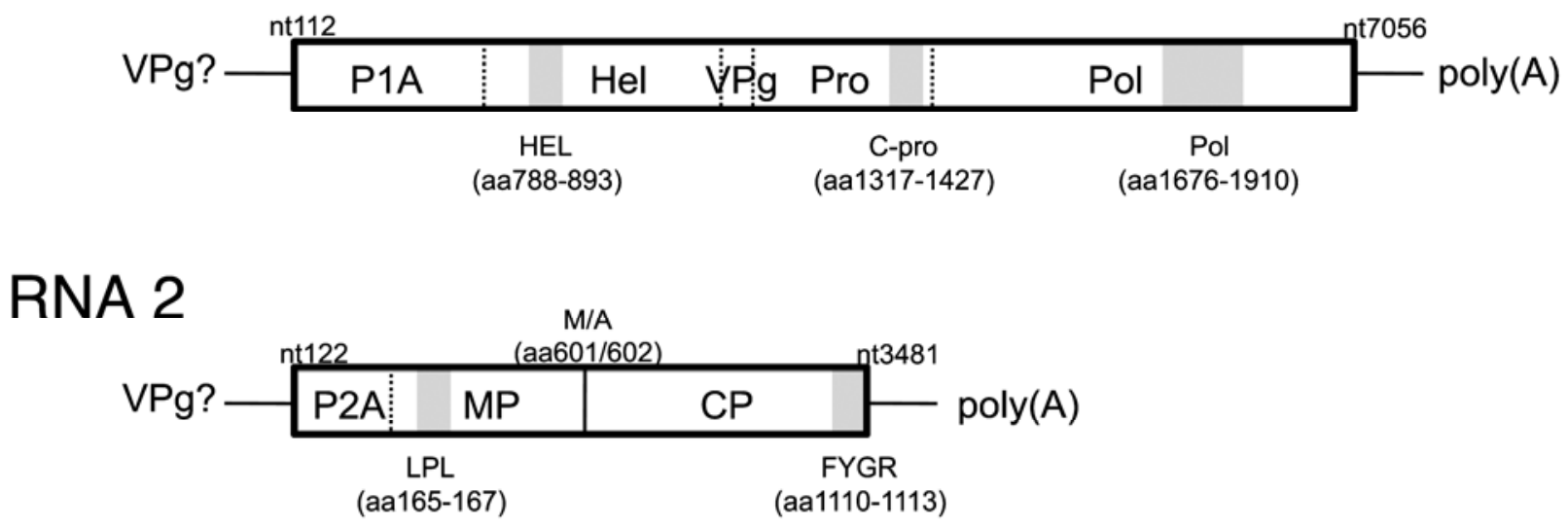

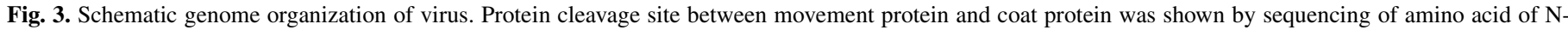

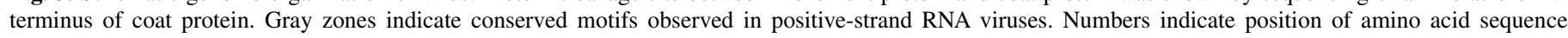
calculated from $\mathrm{N}$-terminus of viral open reading frame. 
suggest that the new virus is a distinct species in the genus Nepovirus. Phylogenetic analyses of Pro-Pol and CP regions were conducted using the ML method (Fig. 4). The virus was grouped with subgroup A nepoviruses in both phylogenies, but distinct from other members reported previously.

Some nepoviruses are transmitted by nematodes of the genera Longidorus, Paralongidorus, and Xiphinema (24). Although we attempted to detect these nematodes in soil collected from melon fields where virus-infected melon plants were found, we were unable to do so. It is also known that nepoviruses are widely spread by pollen and seed transmission (3). Therefore, viral transmission by these modes should be investigated for the virus in the present study. We conclusively demonstrated that the virus could not infect Lagenaria siceraria var. hispida used as rootstock of $C$. melo $\mathrm{cv}$. Prince in the field, perhaps suggesting that it is spread by seed transmission rather than nematode vectors in the field.

In conclusion, biological and molecular characterization of the virus suggests that it is a new species in the genus Nepovirus (subgroup A). We propose the name Melon mild mottle virus (MMMoV) for the new virus.

\section{ACKNOWLEDGMENTS}

We thank T. Mizukubo, T. Ohki, A. Kanda, and H. Hamada for helpful comments and discussion; and S. Nagai and Y. Matsumura for maintaining the plants and materials.
A

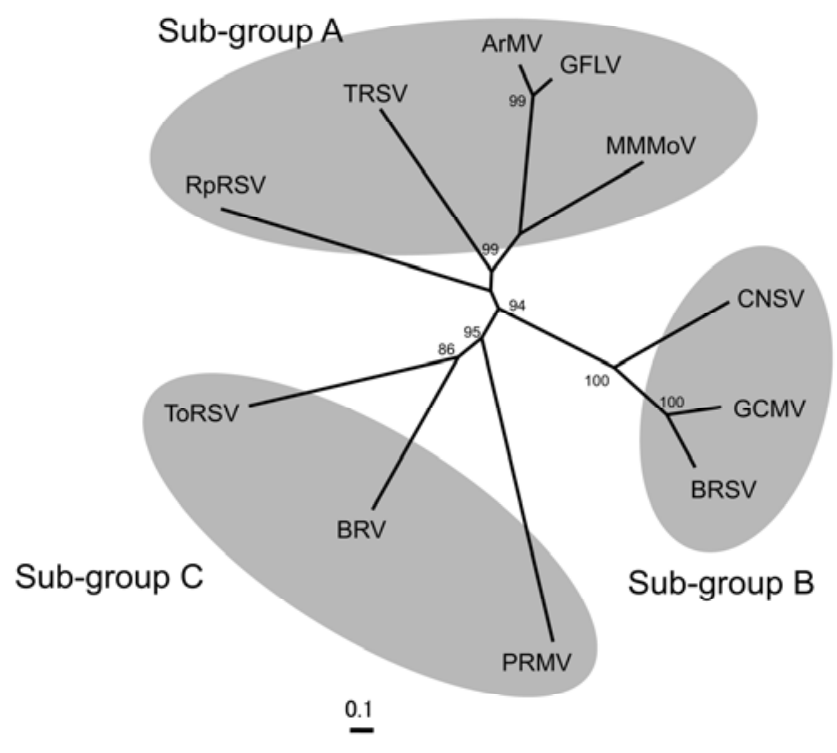

C

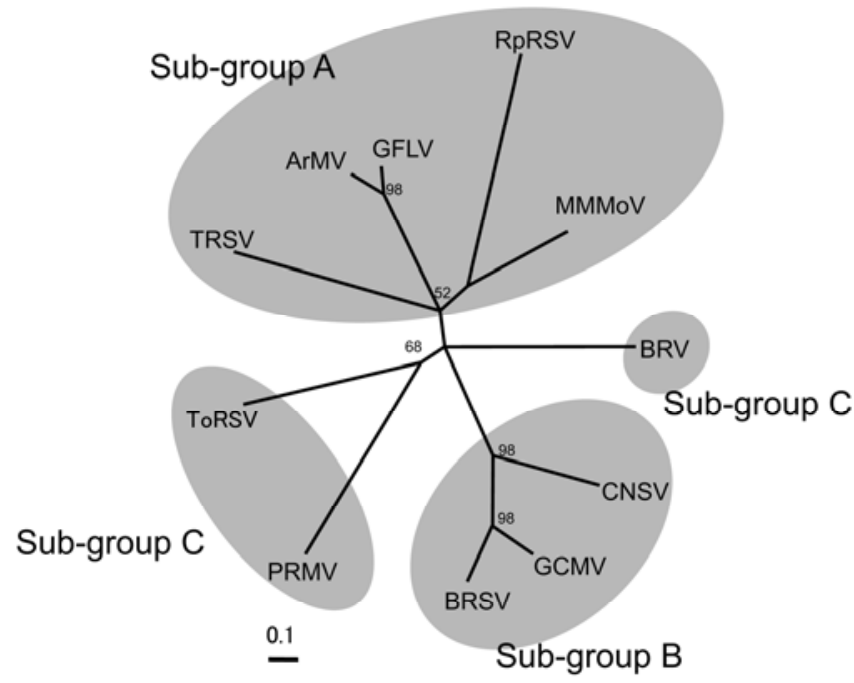

B

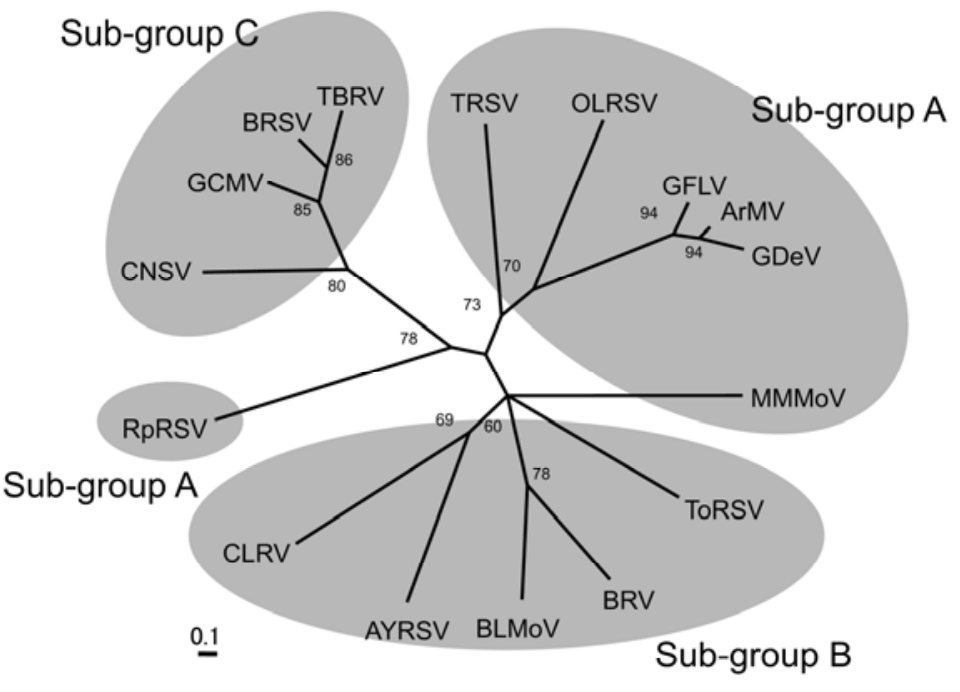

D

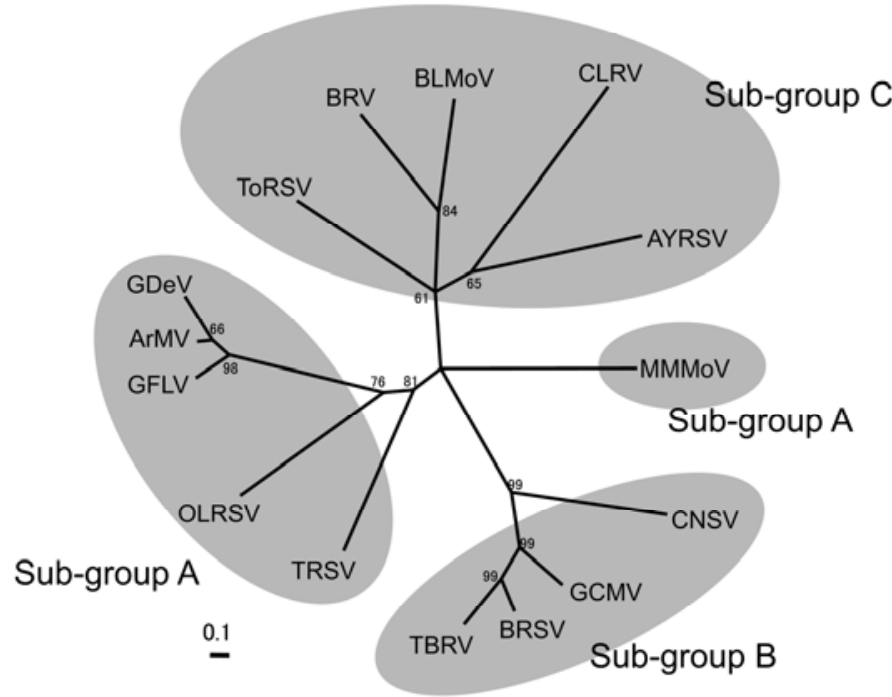

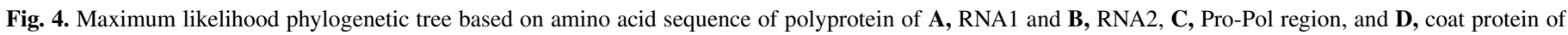
nepovirus species. Horizontal branch length indicates 0.1 replacements per site. Node numbers indicate percentage of supporting puzzling steps. Subgroups of isolates referred from ICTV eighth report (3). GenBank accession numbers, RNA1 and RNA2, and abbreviation used for each virus are as follows: Arabis mosaic virus (ArMV, AY303786, AY017339), Grapevine deformation virus (GDeV, not shown, AY291208), Grapevine fan leaf virus (GFLV, NC_003615, NC_003623), Raspberry ringspot virus (RpRSV, AY303787, AY303788), Tobacco ringspot virus (TRSV, U50869, NC_005096), Beet ringspot virus (BRSV, NC_003693, NC_003694), Cycas necrotic stunt virus (CNSV, NC_003791, NC_003792), Grapevine chrome mosaic virus (GCMV, NC_003622, NC_003621), Olive latent ringspot virus (OLRSV, not shown, AJ277435), Tomato black ring virus (TBRV, NC_004439, NC_004440), Black current reversion virus (BRV, NC_003509, NC_003502), Blueberry leaf mottle virus (BLMoV, U20622, U20621), Cherry leaf roll virus (CLRV, not shown, AAB27443), Peach rosette mosaic virus (PRMV, AF016626, not shown), Tomato ringspot virus (ToRSV, NC_003840, NC_003839), and Artichoke yellow ringspot virus (AYRSV, not shown, ABM65096). 


\section{LITERATURE CITED}

1. Dayhoff, M. O., Schwartz, R. M., and Orcutt, B. C. 1978. A model of evolutionary change in proteins. Volume 5. Pages 345-352 in: Atlas of Protein Sequence Structure. M. O. Dayhoff, ed. National Biomedical Research Foundation, Washington DC.

2. Dessens, J. T., and Lomonodssoff, G. P. 1991. Mutational analysis of the putative catalytic triad of the cowpea mosaic virus $24 \mathrm{~K}$ protease. Virology 184:738-746

3. Fauquet, C. M., Mayo, M. A., Maniloff, J., Desselberger, U., and Ball, L. A. 2005. Virus Taxonomy. Eighth Report of the International Committee on Taxonomy of Viruses. Elsevier Academic Press, San Diego, CA.

4. Gentit, P., Delbos, P. P., Candresse, T., and Dunez, J. 2001. Characterization of a new nepovirus infecting apricot in southeastern France: Apricot latent ringspot virus. Eur. J. Plant Pathol. 107:485-494.

5. Gorbalenya, A. E., Donchenko, A. P., Blinov, V. M., and Koonin, E. V. 1989. Cysteine proteases of positive strand RNA viruses and chymotrypsin-like serine proteases. FEBS Lett. 243:103-114.

6. Gorbalenya, A. E., Koonin, E. V., and Wolf, Y. I. 1990. A new superfamily of putative NTP-binding domains encoded by genomes of small DNA and RNA viruses. FEBS Lett. 262:145-148.

7. Hall, T. A. 1999. BIOEDIT: A user-friendly biological sequence alignment editor and analysis program for Windows 95/98/NT. Nucleic Acids Symp. Ser. 41:95-98.

8. Iwanami, T., Kondo, Y., and Karasev, A. 1999. Nucleotide sequence and taxonomy of satsuma dwarf virus. J. Gen. Virol. 80:793-797.

9. Jeanmougin, F., Thompson, J. D., Gouy, M., Higgins, D. G., and Gibson, T. J. 1998. Multiple sequence alignment with Clustal X. Trends Biochem. Sci. 23:403-405.

10. Kido, K., Tanaka, C., Mochizuki, T., Kubota, K., Ohki, T., Ohnishi, J., Knight, M., and Tsuda, S. 2008. High temperatures activate local viral multiplication and cell-to-cell movement of Melon necrotic spot virus but restrict expression of systemic symptoms. Phytopathology 98:181-186.

11. Koonin, E. V., and Dolja, V. V. 1993. Evolution and taxonomy of positive-strand RNA viruses: Implications of comparative analysis of amino acid sequences. Crit. Rev. Biochem. Mol. Biol. 28:375-430.

12. Koonin, E. V., Mushegian, A. R., Ryabov, E. V., and Dolja, V. V. 1991. Diverse groups of plant RNA and DNA viruses share related movement proteins that may possess chaperone-like activity. J. Gen. Virol. 72:2895-
2903.

13. Le Gall, O., Candresse, T., Brault, V., and Dunez, J. 1989. Nucleotide sequence of Hungarian grapevine chrome mosaic nepovirus RNA1. Nucleic Acids Res. 17:7795-7807.

14. Le Gall, O., Candresse, T., and Dunez, J. 1995. A multiple alignment of the capsid protein sequences of nepoviruses and comoviruses suggests a common structure. Arch. Virol. 140:2041-2053.

15. Margis, R., and Pinck, L. 1992. Effects of site-directed mutagenesis on the presumed catalytic triad and substrate-binding pocket of grapevine fanleaf nepovirus 24-kDa proteinase. Virology 190:884-888.

16. Mayo, M. A., and Fritsch, C. 1994. A possible consensus sequence for VPg of viruses in the family Comoviridae. FEBS Lett. 354:129-130.

17. Mayo, M. A., and Robinson, D. J. 1996. Nepoviruses: Molecular biology and replication. Volume 5. Pages 139-184 in: The Plant Viruses: Polyhedral Virions and Bipartite RNA Genomes. B. D. Harrison and A. F. Murant, eds. Plenum Press, New York.

18. Page, R. D. M. 1996. Treeview: An application to display phylogenetic trees on personal computer. CABIOS 12:357-358.

19. Sakata, Y., and Sugiyama, M. 2002. Characteristics of Japanese cucurbits. Proceedings of the second international symposium on cucurbits. Acta Hort. 588:195-203.

20. Sanfacon, H. 1995. Nepoviruses. Volume 3. Pages 129-141 in: Pathogenesis and Host Specificity in Plant Disease, Viruses and Viroids. R. P. Singh, U. S. Singh, and K. Kohmoto, eds. Pergamon Press, Oxford, UK.

21. Sanfacon, H., Wellink, J., Le Gall, O., Karasev, A., van der Vlugt, D., and Wetzel, T. 2009. Secoviridae: A proposed family of plant viruses within the order Picornavirales that combines the families Sequiviridae and Comoviridae, the unassigned genera Cheravirus and Sadwavirus, and the proposed genus Torradovirus. Arch. Virol. 154:899-907.

22. Strimmer, K., Goldman, N., and von Haeseler, A. 1997. Bayesian probabilities and quartet puzzling. Mol. Biol. Evol. 14:210-211.

23. Strimmer, K., and von Haeseler, A. 1996. Quartet puzzling: A quartet maximum likelihood method for reconstructing tree topologies. Mol. Biol. Evol. 13:964-969.

24. Taylor, C. E., and Brown, D. J. E. 1997. Nematode Vectors of Plant Viruses. CAB International, Wallingford, UK.

25. Yoshida, K., Goto, T., Nemoto, M., and Tsuchizaki, T. 1980. Five viruses isolated from melon (Cucumis melo L.) in Hokkaido. Ann. Phytopathol. Soc. Japan. 46:339-348. 